\title{
Pengaruh Model Pembelajaran Guided Inquiry terhadap Kemampuan Literasi Sains Siswa Kelas X pada Materi Keanekaragaman Hayati di SMA Negeri 1 Wera Tahun Pelajaran 2021/2022
}

\author{
Jofi Kuswanto $^{1)}$, Muh. Nasir ${ }^{1)^{*}}$, Ariyansyah $^{1)}$ \\ ${ }^{1}$ Sekolah Tinggi Keguruan dan Ilmu Pendidikan (STKIP) Bima \\ *perahubima@gmail.com
}

\begin{abstract}
Abstrak: Penelitian ini bertujuan untuk mengetahui model pembelajaran Guided Inquiry terhadap Kemampuan Literasi Sains siswa kelas X pada materi keanekaragaman hayati di SMA Negeri 1 Wera tahun Pelajaran 2021/2022, jenis penelitian adalah eksperimen dengan desain Non equivalent pretest-posttest design. Sampel dalam penelitian ini adalah siswa kelas X SMA Negeri 1 Wera berjumlah 50 orang siswa, kelas X IPA1 berjumlah 25 orang siswa sebagai kelas eksperimen yang diajar dengan model pembelajaran Guided Inquiry dan kelas X IPA2 sebanyak 25 orang siswa sebagai kelas kontrol. Teknik pengambilan sampel menggunakan simple random sampling. Instrumen yang digunakan adalah tes, dan lembar observasi. Hasil penelitian menunjukan bahwa nilai rata-rata pre test kelas kontrol sebesar 66.79 dan post test sebesar 79.29 sedangkan pada kelas eksperimen diperoleh nilai rata-rata pre test sebesar 74.64, posttest sebesar 85.71. Hasil uji hipotesis menunjukan bahwa ada pengaruh model pembelajaran gaided inquiry terhadap Kemampuan Literasi Sains siswa kelas X pada materi keanekaragaman hayati di SMA Negeri 1 Wera tahun Pelajaran 2021/2022, hal ini ditunjukan oleh nilai sig 0,02 kurang dari nilai alpa 0,05 .
\end{abstract}

Kata Kunci: Gaided Inquiry, Kemampuan Literasi Sains.

\section{PENDAHULUAN}

Tujuan pendidikan sains adalah meningkatkan kompetensi siswa untuk dapat memenuhi kebutuhan hidupnya dalam berbagai situasi. Dengan kompetensi itu, siswa akan mampu belajar lebih lanjut dan hidup dimasyarakat yang saat ini banyak dipengaruhi oleh perkembangan sains dan teknologi. Tujuan utama dalam pembelajaran sains adalah untuk membangun literasi sains siswa, yang termasuk dalam literasi sains adalah tentang pemahaman atas prinsip-prinsip sains dan pemahaman bagaimana prinsip-prinsip tersebut dapat dikembangkan (Trianto dalam Refalino, 2020).

Literasi sains merupakan kemampuan esensial yang harus dimiliki manusia untuk mampu mengorganisasi, menganalisis, dan menginterpretasikan setiap informasi yang diperoleh dengan baik (Widayoko et al., 2018). Seseorang dengan literasi sains yang baik akan tanggap terhadap lingkungan sekitar serta interaksinya antara sains, teknologi, dan masyarakat. Literasi sains merupakan kemampuan yang dimiliki siswa untuk mengaitkan peristiwa dan teknologi secara kompleks pada era globalisasi dengan pemahaman sains (OECD, 2013).

Berdasarkan Data Hasil tes kemampuan Literasi Sains Kelas X IPA Tahun Ajaran 2020 di SMA Negeri 1 wera diketahui bahwa dari 152 siswa, hanya 53,94\% siswa dapat menjelaskan fenomena ilmiah, 44,08\% siswa menggunakan bukti ilmiah, 39,48\% siswa mengidentifikasi pertanyaan ilmiah, 40,78\% siswa dapat memahami fenomena, 58,55\% siswa dapat memecahkan masalah. Rendahnya kemampuan siswa dalam memberikan jawaban pertanyaan menunjukan bahwa kemampuan literasi sains siswa masih rendah.

Rendahnya literasi sains juga diakibatkan oleh kurangnya kesiapan siswa dalam mengikuti pembelajaran. Kesiapan mengikuti pembelajaran dapat dimiliki siswa pada pengembangan mental dan pengetahuan prasyarat yang sudah dimiliki dengan melibatkan pengalaman atau pemahaman pengetahuan sebelumnya (Ruseffendi, 2004). Kesiapan siswa dalam mengikuti pembelajaran dapat diartikan dengan kemampuan awal siswa. Kemampuan awal siswa yang dipadukan melalui pengetahuan kekurangan pengetahuan awal tidak 
memungkinkannya untuk maju (Almuntasheri dalam Fa'idah, 2019). Kemampuan awal siswa yang melalui pengetahuan sebelumnya dengan pengetahuan baru akan lebih baik. Pengetahuan awal merupakan hal penting untuk mengetahui seberapa besar informasi atau pengetahuan siswa setelah belajar untuk dijadikan sebagai tolak ukur keberhasilan pembelajaran. Berbagai permasalahan terkait rendahnya literasi sains menjadi penentu langkah dalam membenahi pembelajaran yang akan dilakukan kedepannya. Pembekalan dalam bentuk proses pembelajaran kepada siswa supaya memiliki literasi sains yang baik sangat diperukan.

Salah upaya yang dilakukan agar pembelajaran mampu membuat siswa memahami apa yang sedang dipelajari adalah model pembelajaran guided inquiry, yang dalam pelaksanaanya guru menyediakan bimbingan atau petunjuk yang cukup luas kepada siswa, perancanaanya dibuat oleh guru, siswa tidak merumuskan masalah, dalam model pembelajaran guided inquiry guru tidak melepas begitu saja kegiatan-kegiatan yang dilakukan oleh siswa. Menurut Dahlia (2013) pencapain model pembelajaran guided inquiry memberikan pengaruh pada peningkatan kemampuan literasi sains, di antaranya siswa dilatih untuk menemukan konsep langsung melalui pengalaman sehingga beberapa indikator literasi sains dapat tercapai.

Model pembelajaran guided inquiry akan melatih siswa berani mengemukakan pendapat dan menemukan sendiri pengetahuannya yang berguna untuk memecahkan masalah yang dihadapinya. Penggunaan pembelajaran dengan model guided inquiry secara efesien dan aktif akan mengurangi monopoli guru dalam penguasaan jalannya proses pembelajaran, dan kebosanan siswa dalam menerima pelajaran akan berkurang. Pembelajaran guided inquiry menitik beratkan kepada keaktifan siswa di dalam proses pembelajaran sedangkan guru berperan sebagai fasilitator dan motivator di dalam proses pembelajaran, dan tidak menjadikannya guru sebagai satusatunya sumber belajar. Sehingga siswa yang belum bisa aktif di kelas dapat lebih aktif lagi dengan adanya model pembelajaran guided inquiry.

Model inkuiri terbimbing terbukti mampu meningkatkan berbagai macam keterampilan yang harus dimiliki siswa. Beberapa hasil penelitian menyebutkan bahwa model pembelajaran inkuiri terbimbing dapat melengkapi konsep pengetahuan siswa, dengan keterampilan berpikir kritis, dan kreatif, keterampilan berkomunikasi, bekerja dalam kelompok, dan kemampuan siswa dalam mengevaluasi diri (Gormally et al., 2015). Keaktifan atau proses kerja inkuiri terbimbing dalam mengikuti proses pembelajaran diperlukan guru sebagai fasilitator siswa dalam memahami materi yang dipelajari. Tujuan model pembelajaran inkuiri terbimbing yaitu mengembangkan sikap dan keterampilan siswa berlatih memecahkan masalah sendiri dengan bimbingan guru (Ngalimun, 2018). Memecahkan permasalahan melalui kegiatan penyelidikan merupakan salah satu dari unsur pembelajaran kontekstual. Pembelajaran kontekstual dengan memecahkan permasalahan sehari-hari merupakan salah satu jabaran aspek kompetensi literasi sains. Komponen penyelidikan pada inkuiri terbimbing diharapkan mampu meningkatkan literasi sains siswa

Berdasarkan latar belakang yang diuraikan diatas, dilakukan penelitian pengaruh model pembelajaran guided inquiry terhadap kemampuan literasi sains siswa kelas X pada materi keanekaragaman hayati di SMA Negeri 1 Wera Tahun Pelajaran 2021/2022.

\section{METODE PENELITIAN}

Jenis penelitian yang akan digunakan dalam penelitian ini adalah penelitian eksperimen kuasi yang merupakan penelitian kuantitatif (Lestari, 2021). Desain penelitian ini menggunakan desain "non ekivalen control class", yaitu menggunakan kelas-kelas yang sudah ada sebagai kelompoknya, dengan memilih kelas- kelas yang diperkirakan sama keadaan/kondisinya, dalam hal ini sama berdasarkan tingkat kecerdasan (Sugiyono, 2012)

Tabel 1. Desain Penelitian

\begin{tabular}{cccc}
\hline Kelompok & Pretest & Perlakuan $(\mathrm{x})$ & Posttest \\
\hline IPA1(Eksperimen) & $\mathrm{O}$ & $\mathrm{X}$ & $\mathrm{O}$ \\
IPA2 (Kontrol) & $\mathrm{O}$ & $\mathrm{Y}$ & $\mathrm{O}$ \\
\hline
\end{tabular}

Keterangan:

$\mathrm{X}$ : Model pembelajaran guided inquiry

Y : Model pembelajaran discovery 
$\mathrm{O}$ : Tes awal sama dengan tes akhir

Penelitian ini dilaksanakan di SMA Negeri 1 Wera Tahun Pelajaran 2021/2022 dan waktu penelitian ini dilaksanakan pada bulan September 2021. Populasi dari penelitian ini adalah seluruh siswa kelas X SMA Negeri 1 Wera Tahun Pelajaran 2021/2022. Sampel yang diambil kelas X IPA1 berjumlah 25 orang siswa sebagai kelas eksperimen yang diajar dengan model pembelajaran Guided Inquiry dan kelas X IPA2 sebanyak 25 orang siswa sebagai kelas kontrol yang diajar dengan model Model pembelajaran discovery. Instrumen yang digunakan dalam penelitian ini yaitu tes tertulis berupa soal essay. Tes disusun berdasarkan indikator literasi sains. Data yang diperoleh diolah menggunakan uji statistik berupa uji normalitas (Chi-kuadrat), ujivhomogenitas, dan uji hipotesis (uji t-dua pihak)

\section{HASIL DAN PEMBAHASAN}

Kemampuan literasi sains siswa pada penelitian ini diukur dengan tujuan. Literasi sains diperoleh dari tes soal literasi sains yang dilakukan setelah semua perlakuan selesai. Soal tes literasi sains terdiri dari 5 soal essay

Tabel 2. Deskripsi Data Literasi Sains

\begin{tabular}{cccc}
\hline \multirow{2}{*}{ Kelas } & \multirow{2}{*}{$\mathrm{N}$} & \multicolumn{2}{c}{ Rata-rata } \\
\cline { 3 - 4 } & & Pretest & Posttest \\
\hline Eksperimen & 25 & 74,64 & 85,71 \\
Kontrol & 25 & 66,79 & 79,29 \\
\hline
\end{tabular}

Tes kemampuan literasi sains siswa dilakukan diawal dan dan akhir pembelajaran. Soal yang diberikan sebanyak 5 soal essay yang mewakili dari masing- masing indikator literasi sains menjelaskan fenomena sains, menggunakan bukti ilmiah, mengidentifikasi pertanyaan ilmiah, memahami fenomena sains, dan memecahkan masalah. Pretest tidak berbeda signifikan diberikan diawal penelitian untuk mengetahui sejauh mana kemampuan literasi sains siswa dilihat dari nilai rata- rata pada nilai kelas eksperimen sebesar 74,64 lebih tinggi dibandingkan dengan kelas kontrol sebesar 66,79 Hasil posttest setelah pemberian perlakuan dengan menggunakan model pembelajaran gaided inquiry menunjukan kemampuan literasi sains berbeda signifikan dilihat dari nilai rata-rata pada nilai kelas eksperimen sebesar 85,71 lebih tinggi dibandingkan dengan kelas kontrol sebesar 79,29.

\section{Uji Normalitas}

Uji normalitas dilakukan pada masing-masing kelas kontrol dan kelas eksperimen. Untuk menguji normalitas pada penelitian ini mengunakan uji kalmogorof smirnov pada program SPSS 16.00 dengan taraf signifikan 5\%. Berikut hasil uji normalitas dapat dilihat pada Tabel dibawah ini.

Tabel 3. uji normalitas/uji kalmogorof smirnov

\begin{tabular}{cccccc}
\hline Jenis Tes & & Pretes Eksperime & Posttes Eksperimen & Pretes Kontrol & Posttes Kontrol \\
\hline Normal & Location & 74.64 & 85.71 & 66.79 & 79.29 \\
Distribution & Scale & 11.779 & 7.418 & 9.449 & 7.542 \\
\hline
\end{tabular}

Tabel diatas menunjukan bahwa data kemampuan literasi sains siswa kelas eksperimen dan kelas kontrol memiliki sig $>0.05$ sehingga data variabel kemampuan literasi sains menununjukan bahwa data ini berdistribusi normal.

\section{Uji Homogenitas}

Uji homogenitas pada penelitian ini menggunakan uji test of homogeneity, yang bertujuan untuk mengetahui apakah sampel yang digunakan memiliki varians yang sama atau tidak. Data memiliki varian yang sama apabila signifikansi $>0.05$. jika nilai signifikansi $<0.05$ maka data tidak memiliki varian yang sama. Berikut hasil uji homogenitas dapat dilihat pada Tabel 4.

Berdasarkan hasil uji homogenitas kemampuan literasi sains pretest dan posttest pada kelas eksperimen dan kelas kontrol memiliki sig> 0.05 sehingga dapat disimpulkan bahwa varians antar kelompok bersifat homogen. 
Tabel 4. Uji Homogenitas

\begin{tabular}{cccccc}
\hline & & Levene Statistic & df1 & df2 & Sig. \\
\hline \multirow{4}{*}{ hasil belajar } & Based on Mean & .051 & 1 & 54 & .822 \\
& Based on Median & .062 & 1 & 54 & .804 \\
& Based on Median and with adjusted df & .062 & 1 & 53.473 & .804 \\
& Based on trimmed mean & .061 & 1 & 54 & .806 \\
\hline
\end{tabular}

\section{Uji Hipotesis}

Jika data sudah dikatakan berdistribusi normal dan homogen, maka dilanjutkan dengan melakukan uji prasyarat dengan uji independent t-test. Pengujian hipotesis dilakukan untuk mengetahui adakah pengaruh model pembelajaran gaided inquiry terhadap kemampuan literasi sains siswa kelas eksperimen dan kelas kontrol. Berikut hasil uji hipotesis dapa dilihat pada tabel 5.

Tabel 5. hasil uji hipotesis/uji independent t-test

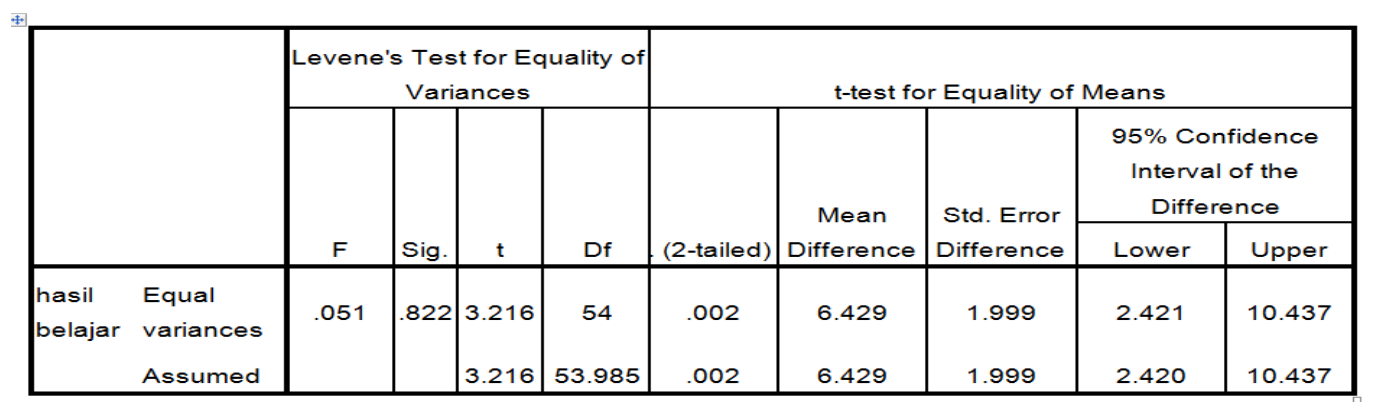

Berdasarkan perhitungan pada tabel 5 , menunjukkan bahwa data model gaided inquirydan kemampuan literasi sains dilihat dari sig.(2-tailed) $<0,05$, maka $\mathrm{H}_{0}$ ditolak dan $\mathrm{H}_{1}$ diterima. Sehingga dapat disimpulkan nilai model pembelajaran gaided inquiry dan kemampuan literasi sains menunjukkan perbedaan yang signifikan, artinya pembelajaran dengan menggunakan model gaided inquiry dapat mempengaruhi kemampuan literasi sains siswa pada materi keanekaragaman hayati

Uji hipotesis yang pertama, signifikansi sebesar 0,000 < 0,05 yang menunjukkan Ho ditolak. Terdapat perbedaan literasi sains antara siswa yang belajar melalui model IT dan siswa yang belajar melalui model DI. Sejalan dengan penelitian sebelumnya yang menunjukkan bahwa proses pembelajaran inkuiri terbimbing berbasis penyelidikan membantu siswa memiliki kesempatan belajar aktif dengan cara bertahap untuk menanamkan literasi sains bagi siswa (Ngertini, 2013). Penelitian ini menyertakan kemampuan awal sebagai variabel kontrol penelitian. Kemampuan awal siswa dilihat dari hasil pretes yang kemudian dikelompokkan menjadi kategori kemampuan awal tinggi dan rendah. Pengujian hipotesis kedua dapat dilihat dari signifikansi pada baris kemampuan. Dari data pengelompokan kemampuan awal diperoleh hasil bahwa rata-rata kemampuan awal kedua kelas hampir sama, yaitu 56,25 dan 54,95 di kelas kontrol

Setelah melakukan uji-t baik pada kelas kontrol maupun pada kelas eksperimen , maka dari perhitungan diperoleh nilai thitung lebih besar dari ttabel yang artinya hipotesis H1 diterima. Dengan kata lain terdapat perbedaan kemampuan literasi sains antara kedua kelas baik yang menggunakan model pembelajaran discovery maupun kelas yang menggunakan model pembelajaran inkuiri terbimbing Dari nilai rata-rata ketercapaian indikator kemampuan literasi sains siswa yang diperoleh, dapat disimpulkan bahwa model pembelajaran inkuiri terbimbing berpengaruh terhadap kemampuan literasi sains siswa. Diperolehnya hasil dari penelitian tersebut dimungkinkan karena dalam pembelajaran menggunakan model pembelajaran inkuiri terbimbing, siswa terlibat berperan aktif dalam proses pembelajaran dan secara kreatif berusaha menemukan permasalahan yang diajukan, saling berinteraksi dengan teman maupun guru, saling bertukar pikiran, sehingga wawasan dan daya pikir mereka berkembang. Pada model pembelajaran inkuiri terbimbing merupakan rangkaian kegiatan pembelajaran yang menekankan pada proses berpikir secara kritis dan analisis untuk mencari dan menemukan sendiri jawaban pada materi fluida statis sedangkan prosedur mengajar pada model pembelajaran discovery mementingkan pengajaran perseorangan, sehingga siswa cenderung tidak mau terlibat. Model pembelajaran inkuiri terbimbing dapat memberikan ruang kepada siswa untuk belajar sesuai dengan gaya belajar mereka, karena materi fluida statis 
akan sangat mudah dipahami siswa jika mereka bisa melihat sendiri fakta yang terjadi yang sering dialami, sedangkan pada model pembelajaran discovery memberikan kesempatan kepada siswa untuk maju sesuai dengan kemampuan masing- masing sehingga pemahaman materi tidak merata diterima

Maka bisa di ketahui bahwa ada pengaruh model pembelajaran gaided inquiry terhadap kemampuan literasi sains siswa di kelas eksperimen dan di kelas kontrol memiliki sig $>0.05$ sehingga data variabel kemampuan literasi sains berdistribusi normal. Hasil uji homogenitas kemampuan literasi sains pretest dan posttest pada kelas eksperimen dan kelas kontrol memiliki sig> 0.05 sehingga dapat disimpulkan bahwa varians antar kelompok bersifat homogeny. Menunjukan bahwa hasil uji t posttest ditemukan nilai sig 2-tailed 0,002. oleh karena nilai sig $<0,05$ maka dapat disimpulkan bahwa ada perbedaan nilai rata-rata kemampuan literasi sains siswa.

\section{SIMPULAN}

Berdasarkan hasil analisis saya dari data dan pengujian hipotesis yang telah dilakukan, Maka bisa di ketahui bahwa ada pengaruh model pembelajaran gaided inquiry terhadap Kemampuan Literasi Sains siswa kelas X pada materi keanekaragaman hayati di SMA Negeri 1 Wera tahun Pelajaran 2021/2022, hal ini ditunjukan oleh nilai sig 0,02 kurang dari nilai alpa 0,05.

\section{Ucapan Terima Kasih}

Ucapan terima kasih kami sampaikan pada kepala SMA Negeri 1 Wera yang telah memfasilitasi dan mengizinkan kami untuk melakukan penelitian, kepada kedua pembimbing bapak Muh. Nasir, M.Pd dan Ibu Ariyansah, M.Sc yang dengan sabar membimbing penulis sampai selesai dan semua pihak yang telah membantu.

\section{Daftar Pustaka}

Dahlia 2013, jurnal pencapaian model pembelajaran (guided inqury) memberikan pengaruh peningkatan kemampuan literasi sains.

Fa'idah R. N, Supriyono K, Susriyati M. (2019). Pengaruh Model Pembelajaran Inkuiri Terbimbing terhadap Literasi Sains Siswa Kelas V SD. Jurnal Pendidikan: Teori, Penelitian, dan Pengembangan Volume: 4 Nomor: 12 Bulan Desember Tahun 2019 Halaman: 1704-1709. Volume: 4 Nomor: 12 Bulan Desember Tahun 2019.

Gormally, C., Brickman, P., Hallar, B., \& Armstrong, N. (2015). Effects of Inquiry-based Learning on Students' Science Literacy Skills and Confidence. International Journal for the Scholarship of Teaching and Learning, 3(2), 32-43. http://doi.org/https://doi.org/10.20429/ijsotl.2009.030216

Lestari, L., Nasir, M., \& Jayanti, M. I. (2021). Pengaruh Model Project Based Learning Terhadap Kemampuan Berpikir Kreatif Peserta Didik Kelas VIII SMP Negeri 2 Sanggar. JISIP (Jurnal Ilmu Sosial dan Pendidikan), 5(4).

Ngalimun. (2018). Strategi dan Model Pembelajaran (edisi revisi). Yogyakarta: Aswaja Presindo.

OECD. (2016). PISA 2015 Assessment and Analytical Framework Science, Reading, Mathematic, Financial Literacy and Collaborative Problem Solving. Paris: OECD Publishing

Rewalino Y.I, Supriyatman, Amirudin Kade. (2020). pengaruh model pembelajaran inkuiri terbimbing terhadap kemampuan literasi sains siswa. Jurnal Pendidikan Fisika Tadulako Online (JPFT) Vol. 8, No. 3, pp. 125 128, p-ISSN 2338-3240, e-ISSN 2580-5924

Ruseffendi, E. T. (2004). Dasar-dasar Penelitian Pendidikan dan Bidang Non Eksakta Lainnya. Bandung: Tarsito

Rupilu, N. P. E. M. (2012). Pengaruh Model Pembelajaran Guided Inquiry Terhadap Kemampuan Berpikir Formal dan Sikap Ilmiah Siswa. Jurnal Pendidikan dan Pembelajaran IPA Indonesia, 2(2).

Sugiyono. Metode Penelitian Pendidikan Pendekatan Kuantitatif, Kualikatif dan R\&D, Bandung: Alfabeta, 2012.

Suharsimi, Arikunto, Prosedur Penelitian Sebagai Pendekatan Praktis, Jakarta: Rineka Cipta 2013. 
Widayoko, A., Latifah, E., \& Yuliati, L. (2018). Peningkatan Kompetensi Literasi Sains Siswa SMA dengan Bahan Ajar Terintegrasi STEM pada Materi Impuls dan Momentum. Jurnal Pendidikan: Teori, Penelitian, dan Pengembangan, 3(11),1463-1467 